\title{
OPTIMALISASI PENJUALAN KRIPIK PISANG DAN GEBLEK DI MASA PANDEMI COVID-19, PEDUKUHAN TURUSAN, GIRIMULYO, KULON PROGO
}

\author{
Ulung Pribadi'1), Juhari'1), Rossi Maunofa Widayat ${ }^{2)}$ \\ 1)Program Studi Ilmu Pemerintahan, Fakultas IImu Sosial dan Politik, Universitas Muhammadiyah Yogyakarta, \\ Yogyakarta, NTB, Indonesia \\ 2)Program Studi IImu Pemerintahan, Fakultas IImu Sosial dan Politik, Universitas Muhhamdiyah Mataram, Mataram, \\ NTB, Indonesia \\ Corresponding author : Ulung Pribadi \\ E-mail : ulungpribadi2@gmail.com
}

\section{Diterima 02 Oktober 2021, Direvisi 04 November 2021, Disetujui 04 November 2021}

\begin{abstract}
ABSTRAK
Pendapatan pengusaha UMKM (Usaha Mikro Kecil Menengah) Kripik Pisang Ibu Siti dan Geblek Buk Tuminem mengalami penurunan semenjak pandemi covid-19. Selain itu juga adanya beberapa keterbatasan pada kedua UMKM tersebut pada proses penjualan antara lain, packaging produk masih sederhana dengan cara manual sehingga produk yang akan dipasarkan tidak tahan lama, belum memiliki label kemasan, dan pemasaran produk masih belum luas. Dari permasalahan mitra tersebut UMY melalui program pengabdian kepada masyarakat yang disinergikan melalui Kuliah Kerja Nyata (KKN) memiliki beberapa program kegiatan untuk mengatasi permasalahan mitra. Program ini ditujukan untuk meningkatkan kualitas penjualan serta pemasaran Kripik Pisang Ibu Siti dan Geblek Ibu Tuminem ditengah pandemi covid-19. Kedua UMKM telah diberikan sosialisasi serta pelatihan menggunakan media sosial di era digitalisasi dan untuk membantu pemilik UMKM dalam mengatasi penurunan penjualan di masa pandemi Covid-19. Tim pengabdi telah membuatkan akun media sosial, dan juga telah membuatkan logo dan pamflet yang nantinya akan disebarkan melalui media sosial agar dapat meningkatkan hasil penjualan. Serta menciptakan packaging product yang menarik sehingga menambahkan daya tarik konsumen.
\end{abstract}

Kata_kunci : optimalisasi; UMKM “Kripik Pisang” "Geblek”; media sosial; manajemen pemasaran.

\begin{abstract}
Entrepreneurs of "kripik pisang" led by Mrs. Siti and "geblek" led by Mrs. Tuminem are facing big problems, especially in the era of the covid-19 pandemic. First, these Micro, Small and Medium Enterprises ("MSMEs") do not utilize the internet and social media networks to market their products. Second, they haven't packaging products that attract consumers' attention. Third, they do not manage their finances well. Therefore, they get a small income and even tend to decline. The UMY Community Service Team and KKN students have implemented programs and activities to empower these entrepreneurs. First, this team has socialized and taught how to create attractive accounts on the internet and social media to expand product marketing. Second, this team has helped the small entrepreneur to package and label innovative products. Third, this team helps the entrepreneur to properly manage the company's finances. This team hopes to realize the goal, namely that small entrepreneurs can expand product marketing and increase consumers. That way, they can get a significant increase in income.
\end{abstract}

Keywords: "UMKM"; "kripik pisang" "geblek"; financial management; social media; marketing management

\section{PENDAHULUAN}

Pembangunan dan perkembangan perekonomian negara - negara berkembang seperti di Indonesia sangat bergantung pada "Usaha mikro kecil dan menengah" (UMKM). Hal ini dikarenakan "usaha mikro kecil dan mengengah" banyak menyerap tenaga kerja sehingga berdampak pada berkurangnya jumlah pengangguran dan dapat meningkatkan pendapatan per kapita suatu negara. Sektor usaha mikro, kecil dan menengah (UMKM) juga memiliki kontribusi dalam hal meningkatkan jumlah produk domestic bruto (Pakpahan, 2020).

"Usaha Mikro Kecil Menengah" atau disingkat UMKM memiliki peran penting dalam pertumbuhan ekonomi di Indonesia. Peran tersebut diantaranya adalah mampu menyerap tenaga kerja, mengatasi masalah kemiskinan dan membantu pendistribusian 
hasil-hasil pembangunan (Hapsoro, B. B., Palupiningdyah, P., \& Slamet, 2019). Di Indonesia, sektor bisnis seperti fashion, kuliner dan kerajinan menjadi yang paling diminati. Sedangkan UMKM dalam bidang jasa tidak banyak diminati dikarenakan tantangan untuk berinovasi memberikan pelayanan yang cepat dan efisien yang didukung dengan penggunaan teknologi (Koeswandi, T. A., \& Primaskara, 2020). Perannya yang penting sebagai 'tulang punggung' perekonomian Indonesia tidak ditunjukan dengan pertumbuhan yang signifikan setiap tahun. Pertumbuhan UMKM di Indonesia terus menurun terutama dalam industri jasa (Laura Hardilawati, 2020).

Penyebabnya

kegagalan berkembangnya UMKM terletak pada fungsi saluran pemasaran yang tidak optimal. Saluran pemasaran yang baik mencakup segala upaya pemenuhan kebutuhan produk/jasa mulai dari produsen, supplier, distributor hingga konsumen dengan menciptakan \& menawarkan nilai. Dari hulu ke hilir, saluran distribusi yang efektif dibangun dengan trust dan komitmen agar target perusahaan dapat tercapai (Sugiri, 2020). Pandemi covid-19 yang melanda Indonesia sangat mempengaruhi beberapa sektor terutama pada sektor perekonomian, yang dalam hal ini para pengusaha UMKM karena menurunnya omset pendapatan. Mulai menurunnya omset pendapatan para pelaku UMKM ini salah satunya dikarenakan adanya kebijakan pemerintah untuk memutus mata rantai wabah covid-19 dengan PSBB (Pembatasan Sosial Bersakala Besar) di berbagai wilayah. Tujuan dari diberlakukannya kebijakan tersebut untuk menjaga keselamatan para warganya dimasa pandemi ini sehingga menurunnya daya beli konsumen pada usaha bisnis para UMKM tersebut (Alfrian, G. R., \& Pitaloka, 2020).

Kabupaten Kulon Progo terletak pada Provinsi Daerah Istimewa Yogyakarta bagian barat yang memiliki berbagai tempat wisata yang sangat menarik untuk dikunjungi. Daerah Kabupaten Kulon Progo yang letaknya sangat strategis dan keadaan alamnya yang memberikan pesona tersendiri, baik yang berupa gunung, pantai, waduk, dataran rendahnya, maupun panorama alamnya yang indah serta didukung oleh potensi wisata daerah lain yang ada, maka memperkuat posisi dan peranan Kabupaten Kulon Progo sebagai daerah tujuan wisata. Selain potensi wisata ada juga potensi kuliner unggulan khas kulon progo yaitu geblek. Geblek merupakan makanan khas dari Kulon Progo yang terbuat dari singkong dan pati. Makanan ini memiliki ciri khas dari bentuknya yang bulat membentuk angka delapan dan teksturnya yang kenyal tapi nikmat. Geblek ini sangat terkenal di Kulon Progo dan sekitarnya, sehingga di jadikan salah satu icon kuliner di sana.

Pandemi virus corona sangat berpengaruh dalam berbagai segi kehidupan. Dampak yang paling besar dirasakan pada sektor ekonomi. Tidak hanya industri besar namun UKM juga merasakan dampaknya. Adanya penurunan aktivitas jual beli dan tutupnya tempat wisata menjadikan penjualan geblek dan kripik pisang ini di Kecamatan Girimulyo menurun. Kendala umumnya dirasakan oleh para industri rumahan yang masih belum menggunakan platform online untuk memasarkan produknya, dari masih kurangnya pengetahuan dan pengalaman menjadi hambatan utamanya. Sementara dalam masa pandemi seperti sekarang para pengusaha besar ataupun kecil berlombalomba untuk memasarkan produknya melalui online. Tujuan dilakukannya kegiatan ini yaitu untuk meningkatkan penjualan produk kemasan melalui pemasaran online, yang akan berperan penting terhadap daya tarik konsumen terutama di masa pandemi saat ini.

\section{METODE}

Melalui program KKN PPM dan juga dibantu oleh sejumlah mahasiswa yang saat ini sedang melaksanakan KKN di Pedukuhan Turusan dapat membatu tim pengabdian untuk memberikan sosialisi, pelatihan serta pendampingan kepada UMKM Kripik Pisang dan Geblek agar dapat mengoptimalkan pemasaran produk sehingga tetap bertahan dan berproduksi di masa pandemi covid-19 dengan menggunakan mengubah kemasan dan metode pemasarannya menggunakan media sosial. Kegiatan ini dilaksanakan selama bulan Januari-Juli 2021, bentuk dari kegiatan ini nantinya akan lebih pada berupa sosialisasi, pelatihan, serta pendampingan dengan kedua UMKM yakni pertama, UMKM Kripik Pisang lbu Siti dan Geblek Ibu Tuminem. Untuk itu solusi yang ditawarkan pertama, sosialisasi memperkenalkan media sosial kepada kedua UMKM mengenai fungsi media sosial terutama sebagai alat yang digunakan untuk memasarkan produk-produk olahan makanan yang akan dijual ke konsumen, selain itu juga menjelaskan pengertian dan fungsi desain serta label makanan sebuah produk. Kedua, pelatihan dalam hal ini nantinya tim pengabdi akan mengadakan pelatihan mengoperasionalkan media sosial kepada UMKM dengan mengundang tim dosen dari Universitas Muhammadiyah Yogyakarta sebagai nara sumber pada kegiatan tersebut. Ketiga, pendampingan dalam hal ini tim 
pengabdian yang dibantu dengan sejumlah mahasiswa KKN dan tim dosen memberikan pendampingan bagaimana packaging produk dan upload di media sosial mengenai produk yang nantinya akan dipasarkan.

Sebelum melakukan pengabdian tim bersama anggota mahasiswa KKN yang berjumlah 10 orang yang ikut mempersiapkan pelaksanaan kegiatan KKN-PPM dengan kegiatan meliputi (1) Penyusunan jadwal agenda, persiapan ini dilakukan untuk menyusun jadwal-jadwal kegiatan bersama anggota KKN, agar jadwal agenda yang sudah dipersiapkan sesuai dengan jadwal program kegiatan yang sudah disusun oleh anggota KKN. Sehingga kegiatan KKN-PPM juga masuk dalam kegiatan program pada mahasiswa KKN selama proses kegiatan KKN. (2) Modul materi pelatihan, persiapan ini dilakukan oleh tim pengabdian masyarakat dengan nantinya sesuai jadwal yang telah ditentukan akan mengundang nara sumber-nara sumber terkait program kegiatan yang akan disampaikan dalam bentuk sosialisasi, pelatihan yang pesertanya dari kedua UMKM yakni pertama, UMKM Kripik Pisang dan Geblek. Nantinya para peserta akan dibagikan modul/ materi dari setiap kegiatan yang diikuti. (3) Persiapan sarana dan prasarana, persiapan ini dilakukan antara tim pengabdi masyarakat dengan anggota KKN yang berjumlah sepuluh oang untuk berkoordinasi dengan kedua mitra terkait ketersediaan sarana dan prasarana selama proses kegiatan. (4) Koordinasi lapangan, persiapan ini dilakukan dengan melibatkan anggota KKN yang nantinya memiliki peran dalam setiap kegiatan sehingga diharapkan semua proses kegiatan berjalan dengan lancar, dan setiap kegiatan anggota KKN dibagi menjadi dua tim yang memiliki tugas dan tanggungjawab yang berbeda-beda di setiap kegiatan yang dilaksanakan. (5) Sosialisasi dengan mengumpulkan stakeholders, persiapan ini dilakukan tim pengabdian dengan mengundang seluruh anggota kedua UMKM Ketua RW dan RT Pedukuhan Turusan, tokoh masyarakat, dan tokoh pemuda. Maksud serta tujuan pemberitahuan terkait kegiatan pengabdian ini serta menerima masukan dari berbagai pihak mengenai program-program yang akan dilaksanakan.

\section{HASIL DAN PEMBAHASAN}

UMKM Kripik Pisang dan Geblek yang dimiliki oleh Bu Siti dan Bu Tuminem bertempat didusun Turusan, Pendoworejo Girimulyo Kulon Progo DIY. Dilihat dari aspek geografisnya merupakan daerah yang stategis, karena adanya bandara baru yang ada di Kulon Progo yang secara tidak langsung juga memberikan pengaruh terhadap perekonomian masyarakat sekitar. Untuk memanfaatkannya maka Ibu Siti membuat usaha keripik pisang yang berbahan dasar pisang kepok putih yang banyak di ketemukan di areal persawahan di Desa Pendoworejo. Tidak hanya Ibu Siti, Ibu Tuminem juga memanfaatkannya untuk usaha Geblek yang sebelumnya telah berdiri sejak kurang lebih selama 25 Tahun yang lalu. Ibu Tuminem meneruskan usaha milik ibunya dulu berkat keuletan dan kegigihannya usaha ini masih tetap berjalan sampai saat ini. Berbeda dengan usaha kripik pisang yang di jalankan oleh Ibu Siti, yang baru 1 tahun dalam menjalankan bisnis ini.

Dari hasil observasi yang tim pengabdi lakukan pada kedua mitra pembuatan pada tanggal 18 Januari, dimana kedua mitra merasakan dampak yang disebabkan oleh pandemi covid-19. Kedua mitra memberikan usulan terkait program yang nantinya akan tim pengabdi lakukan, pertama agar dibantu dalam proses pemasaran, kedua dalam proses kemasan. Obeservasi ini dilakukan agar tercapainya kesepakatan antara kedua belah pihak dan menghindari adanya kesalahpahaman. Pada tanggal 31 Januari tim pengabdi mengadakan kegiatan sosialisasi, serta pendampingan pembuatan kripik pisang dan geblek melalui kemasan yang ada logo serta pamflet foto pada produk UMKM kripik pisang dan geblek. Hasil dari kegiatan ini kedua mitra dapat memahami pentingnya logo dan pamflet sebagai branding product yang nantinya bisa digunakan untuk pemasaran menggunakan media sosial. Kegiatan sosialisasi serta pendampingan pembuatan kripik pisang dan geblek dapat dilihat pada gambar 1 dan 2.

Hal yang sama juga dirasakan oleh UMKM Geblek, dimana Ibu Tuminem juga sangat antusias dengan kegiatan yang dilaksanakan mengenai sosialisasi, serta pendampingan pembuatan geblek melalui kemasan yang ada logo serta pamflet foto pada produk pada tanggal 1 Februari yang diikuti oleh tujuh orang dari UMKM Geblek. Ibu Tuminem begitu antusias karena produk gebleknya dalam kemasan yang baru telah memiliki logo (Gambar2). Dengan adanya logo dapat membantu meningkatkan penjualan produk baru perusahaan karena pelanggan dapat mengasosiasikan kualitas produk yang telah dikenal masyarakat luas dengan kualitas produk baru menggunakan logo yang sama. Suatu logo mampu mempengaruhi konsumen agar lebih tertarik membeli produk yang dipasarkan. Selain itu, masyarakat juga akan lebih mudah mengingat produk. Secara tidak langsung bahwa branding mampu memberikan 
banyak manfaat, termasuk dalam memengaruhi calon konsumen, brand yang ditawarkan ke konsumen dengan perlahan akan memengaruhi mereka untuk membeli produk.

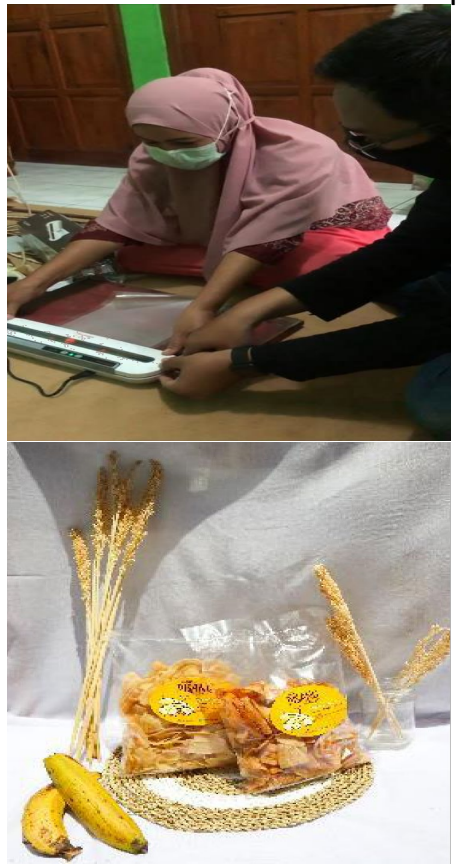

Gambar 1. Pembuatan logo dan pamflet, foto produk UMKM Kripik Pisang

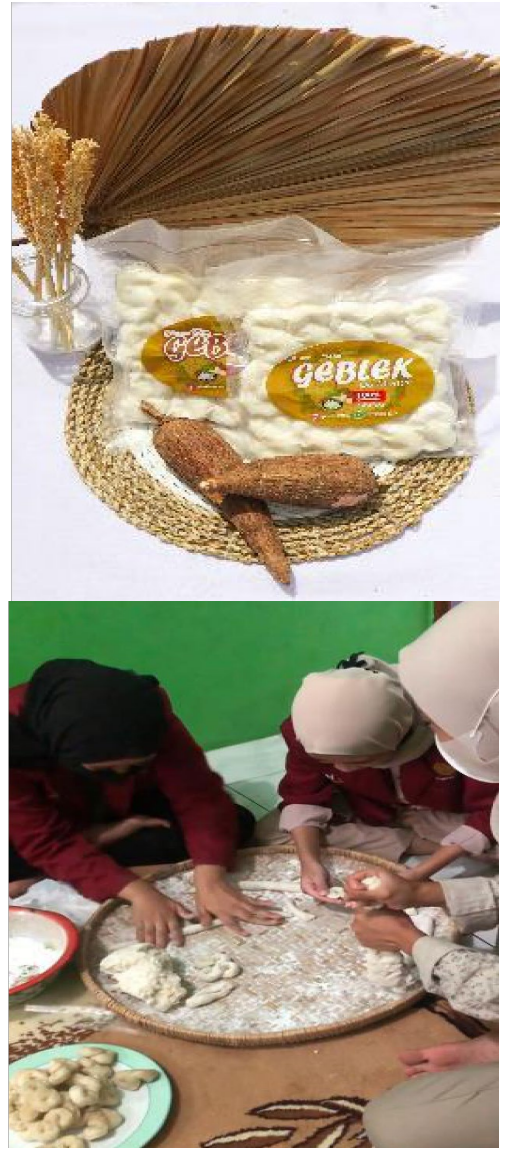

Gambar 2. Pembuatan logo dan pamflet, foto produk UMKM Geblek
Selain itu juga kemasan menjadi salah satu unsur yang sangat penting bagi suatu produk. Fungsi utama suatu kemasan adalah sebagai identitas produk, melindungi produk, menjadi daya tarik bagi konsumen, menyajikan informasi yang dibutuhkan seputar produk. Lebih dari sekedar pembungkus, kemasan merupakan branding. Apapun jenis barang atau produk yang akan dijual ketika diberi merek dan dikemas akan memberikan nilai lebih. kemasan itu dibuat bagus dan memiliki personality yang kuat akan mampu meningkatkan rasa percaya dari konsumen saat memilih produk yang akan dibelinya. Ketika sebuah pengemasan dibuat dengan bentuk unik dan warna yang menarik akan lebih mudah menarik perhatian. Dan selanjutnya, konsumen tersebut akan mengambil, lebih banyak mengamati, dan mempertimbangkan untuk membelinya. Artinya, pengemasan sebagai salah satu senjata, telah berjalan dengan baik

Setelah kedua UMKM memiliki kemasan baru yang disertai dengan logo, upaya berikutnya yang dilakukan oleh tim pengabdian untuk memakismalkan penjualan ditengah pandemi yaitu dengan mengadakan kegiatan sosialisasi tentang pemasaran online yang dilakukan pada tanggal 15-16 Februari (Gambar 3). Tidak hanya pengenalan melalui pemasaran online, tim pengabdian juga melalukan kegiatan kepada kedua mitra untuk didampingi dalam mengelola platform penjualan online. Yang dalam hal ini kegiatan yang dilakukan dengan melakukan pendampingan pengelolaan media sosial sebagai penjualan online. Dimana dalam progam kerja ini kita membantu mitra dalam mengolah dan menjalankan media yang dijadikan sebagai media promosi. Tim pengabdi juga membantu pendampingan ini dengan cara tetap memantau agar platform yang dijadikan media promosi tetap aktif dijalankan. Selain itu, kami juga membantu untuk membuat caption yang menarik di dalam platformnya agar orang yang melihat lebih tertarik untuk membeli produk dari Keripik Pisang Ibu Siti dan Geblek Ibu Tuminem.

Metode yang dilakukan dalam program kerja ini yaitu membantu mitra dengan cara pembuatan foto dan video dari produk yang ada dan pengemasan produk dengan menggunakan mesin vaccum dan mesin press. Dengan melakukan pengambilan gambar dan perbaikan kemasan dari produk akan menambah daya tarik dalam foto tersebut akan meningkatkan kualitas tampilan produk. Hasil dari pengambilan gambar tersebut akan digunakan sebagai tampilan produk pemasaran online di sosial media. Harapan setelah dilakukan program kerja ini yaitu meningkatkan 
kualitas produk mitra dan menambah daya tarik konsumen untuk membeli produk tersebut. Dan mempengaruhi peningkatan penjualan bisnis mitra dalam pemasaran online di sosial media

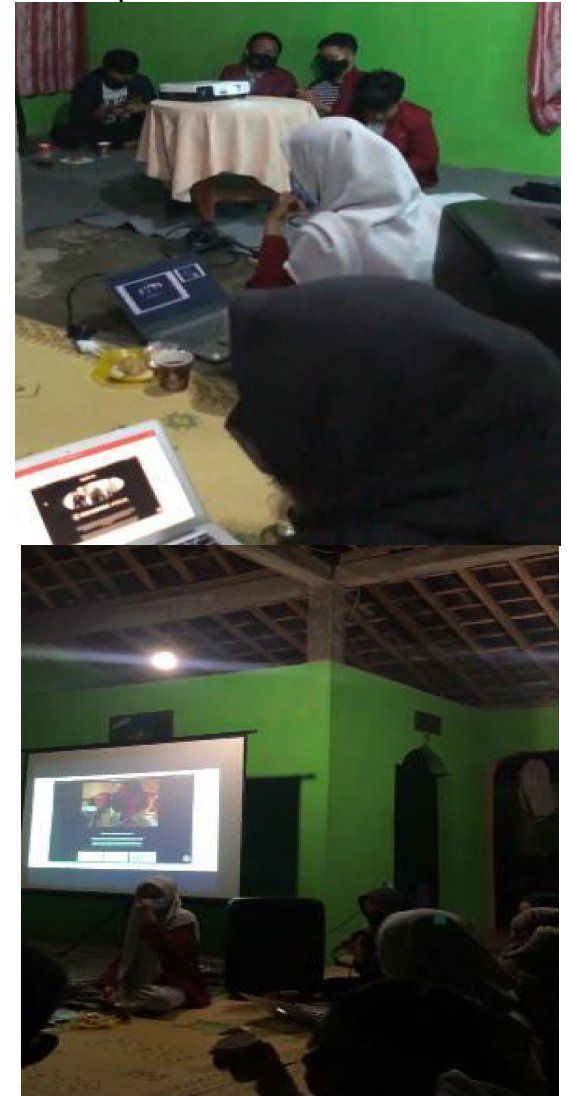

Gambar 3. Kegiatan sosialisasi melalui pemasaran online

\section{SIMPULAN DAN SARAN}

UMKM kripik pisang dan Geblek telah menggunakan packaging product yang lebih menarik sehingga menambahkan daya tarik konsumen. Kedua UMKM telah memiliki media sosial untuk meningkatkan penjualan produk kemasan melalui pemasaran online, yang akan berperan penting terhadap daya tarik konsumen terutama di masa pandemi saat ini. Kami berharap program kerja yang telah kami laksanakan di Desa Pendoworejo dapat dilanjutkan dan membawa manfaat kepada mitra sehingga dapat mengoptimalkan pemasaran produk dan tetap berproduksi di masa pandemi covid-19.

\section{DAFTAR RUJUKAN}

Alfrian, G. R., \& Pitaloka, E. (2020). STRATEGI USAHA MIKRO, KECIL, DAN MENENGAH (UMKM) BERTAHAN PADA KONDISI PANDEMIK COVID 19 DI INDONESIA. SENTRINOV, 6(2), 139146.

Hapsoro, B. B., Palupiningdyah, P., \& Slamet, A. (2019). Peran Digital Marketing sebagai Upaya Peningkatan Omset Penjualan
Bagi Klaster UMKM di Kota Semarang. Jurnal Abdimas, 23(2), 117-120.

Koeswandi, T. A., \& Primaskara, E. A. (2020). Analisis Saluran Pemasaran Terintegrasi UMKM Badii Farm Purwakarta dalam Meningkatkan Volume Penjualan. Jurnal IImu Manajemen Dan Bisnis, (March). https://doi.org/10.17509/jimb.v11i1.23784

Laura Hardilawati, W. (2020). Strategi Bertahan UMKM di Tengah Pandemi Covid-19. jurnal akuntansi dan ekonomika. Jurnal Akuntansi Dan Ekonomika, 10(1).

Pakpahan, A. K. (2020). COVID-19 dan Implikasi Bagi Usaha Mikro, Kecil, dan Menengah. Jurnal Ilmiah Hubungan Internasional, 20(April).

Sugiri, D. (2020). Menyelamatkan Usaha Mikro, Kecil dan Menengah dari Dampak Pandemi Covid-19. Media Pengkajian Manajemen Dan Akuntansi, 19(1), 76-86. https://doi.org/10.32639/fokusbisnis.v19i1 .575 